\title{
Analysis of the Problem Solving Ability of Mathematics Education Students Using the Trigonometry Module
}

\author{
Rahmatya Nurmeidina ${ }^{1}$, Ahmad Lazwardi $^{2}$, Arif Ganda Nugroho ${ }^{3}$ \\ \{rahmatya.dina@gmail.com ${ }^{1}$, lazwardiahmad@gmail.com ${ }^{2}$, arifgnugroho@gmail.com $\left.{ }^{3}\right\}$ \\ Universitas Muhammadiyah Banjarmasin, Jalan Gubernur H Syarkawi Barito Kuala
}

\begin{abstract}
This study aims to analyze students' problem-solving abilities in the mathematics education study program after learning using modules in the trigonometry course. This research is a qualitative descriptive study. The subjects in this study were students of mathematics education semester I of low, medium, and high ability. The data collection technique is a test using problem-solving questions, interviews, and documentation. The data analysis technique used document analysis techniques. Data analysis was carried out by collecting data, reducing data, presenting data, and finally drawing conclusions and verifying data. The result of this research is that the subject can understand the problem by identifying the information that appears on the issue and determining the method or formula used in solving the problem. After that, solve the trigonometric problems given and check the results of the answers that have been done. The trigonometric material provided in the problem-solving ability test is the size of the angle, trigonometry ratio, and trigonometric identity. Students still have difficulty completing proving trigonometric identities because students are still confused and also experienced misconceptions in trigonometric and algebraic properties to confirm this trigonometric identity.
\end{abstract}

Keywords: Problem solving ability, Trigonometry, Module

\section{Introduction}

Learning mathematics is not just learning to count, but students can also develop problemsolving skills. This is by the objectives of learning mathematics as stated in Permendiknas No. 22 of 2006, and mathematics lessons aim to make students have the ability to understand mathematical concepts, explain the relationship between images and apply concepts or algorithms, in a flexible, accurate, efficient and precise manner, in solving a problem. Therefore, problem-solving is an ability that a mathematics teacher must have to develop students' problem-solving skills during mathematics learning.

The problem-solving ability is Problem Solving according to Hendriana, H., Rohaeti, EE, \& Sumarmo, U [1] which is an essential ability in learning mathematics, helping individuals think analytically, learning mathematical problem solving, in essence, is learning to think, reason and apply the knowledge that is already owned, solving mathematical issues helps to think critically, creatively and develop other mathematical problem-solving skills. Polya [2] proposes four problem-solving principles that are interesting and ensure that the mathematical principles learned will be transferred as widely as possible.

Polya's technique is known as heuristics (serving to discover), namely strategies that can help problem-solving. The heuristics method is: a. Understand the problem by asking what is 
unknown, what data is being given, what kind of problem conditions, and doing things like etching the image. b. Creating a completion plan (creating a mathematical model), such as finding the relationship between data and anonymous information. c. Solve problems by implementing a complete program and checking each step. d. Re-examine procedures and interpret solutions to issues (results) obtained. Problem-solving skills are essential for mathematics education students as prospective teachers. A teacher or future mathematics teacher is required to be able to design learning that can explore problem-solving [3]

Trigonometry is a basic introductory course in mathematics education programs because trigonometry is a subject taught in schools. Basic concepts are used in other issues such as Tas algebra, complex functions, calculus (limits, derivatives, integrals), and geometry. Trigonometry is a topic that is difficult for teachers and students to understand [4]. The observations on students [5] who are taking trigonometry courses show that students still have difficulty working on trigonometric questions, especially questions that cannot be answered directly by using memorized concepts or problem-solving problems.

Problem-solving skills are one of the soft skills that must be answered—owned by students. Problem-solving skills can be trained by frequently solving math problem-solving problems. Besides, initial research shows that students still have difficulty solving trigonometric issues, especially in problem-solving topics. Besides that, students also experience misconceptions [6]. Based on the interview results, it was also found that students were not used to and motivated to work on problems with problem-solving abilities; they tended to give up first before trying to answer and preferred to do routine questions about understanding concepts only. In higher education, lecturers play an essential role in providing facilities or conditioning lectures with the right method, one of which is doing modules [7].

The learning module can make students easier to practice problems with problem-solving abilities independently. Research by [8] states that learning mathematics using modules is beneficial. Students give a positive response to learning using the Trigonometry module. Thus learning using modules can be used as a solution to develop students' problem-solving abilities. The learning objectives use modules to facilitate students' learning course material and develop problem-solving skills [9]. Furthermore, it will be seen how the description of the solving ability of mathematics education students after using the module. Thus, this study analyzes students' problem-solving skills in the mathematics education study program after learning using modules in the trigonometry course.

\section{Method}

This study aims to qualitatively explain the problem-solving abilities of mathematics education students after learning using modules. The subjects in this study were 6 first semester mathematics education students at the Muhammadiyah University of Banjarmasin who received trigonometry courses using modules. The data collection techniques were students answered 3 problems solving trigonometric problems, deep interview, and documentation of all data. The research instrument consisted of 3 problem-solving questions with the question material indicators as follows.

Table 1. Instruments problem-solving problems

NO Question material indicators $\quad$ Problem


1. Angle and their measure

2. The Trigonometric Functions of an Acute Angle of a Right Triangle

3. The trigonometric identity.
Earth rotates to arrive at 1 complete rotation takes 23 hours 56 minutes 4 seconds. What is the radian of the earth's rotation in 1 second? A child stands 3 meters from the base of the tree. The child looks at the top of the coconut tree at an angle of $60^{\circ}$. How tall is the coconut tree, if the child is $160 \mathrm{~cm}$ tall? Draw a sketch of the illustration

Show that

The data analysis technique used document analysis techniques. The results of the students' answers were analyzed based on 4 aspects of Polya's steps, namely understand the problem, creating a complete plan, develop a problem-solving plan, and re-check the problem-solving results. Data analysis was performed by collecting data, data reduction, data presentation, and finally drawing conclusions and data verification. Data mining was carried out in-depth, originating from 3 problems solving trigonometric problems. The trigonometric material given in the problem-solving ability test is the size of the angle, trigonometry ratio, and trigonometric identity.

\section{Results and Discussion}

The subject's problem-solving ability was analyzed through the tests given to them and reviewing the way they answered previous tests. Furthermore, based on the analysis of students' answers in doing the problem-solving ability test questions and interviews, the results obtained were reviewed based on 4 aspects of Polya's steps, namely understanding the problem, making a solution plan, compiling a problem-solving plan, and checking the results of problem-solving as follows.

\subsection{Understand the problem}

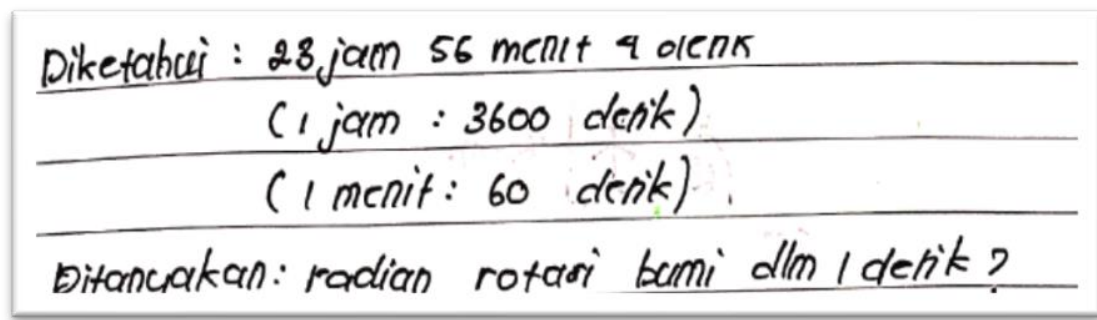

Fig. 1. Students write down information about the questions known and are asked for the first question 


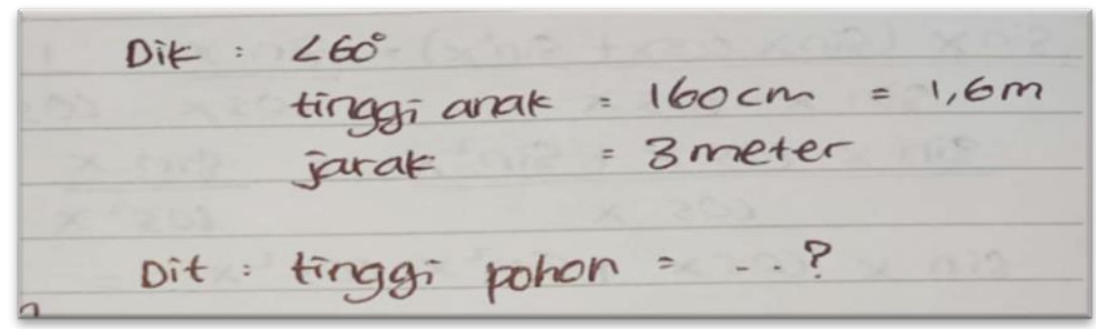

Fig. 2. Students write down information about the questions known and are asked for the first question

The subject can understand the problem by explaining what information is obtained from the situation. In the first and second questions, students generally write information about the questions with known and questioned techniques in full, such as in Figure 1 and Figure 2. However, some write down the story that is known as in Figure 3 Equations and formulas should be punctuated in the same way as ordinary text but with a space before the punctuation mark.

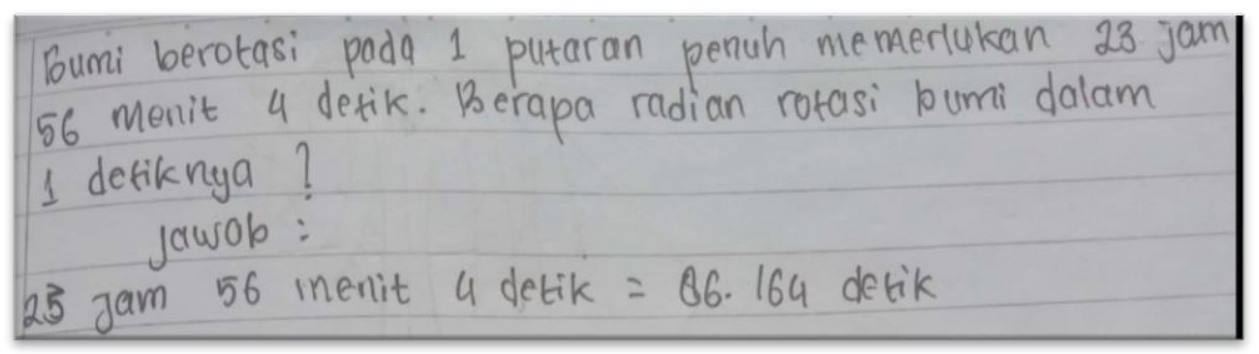

Fig. 3. Students write down information about questions directly, without being noticed and asked.

In the third question, because of the shape, the problem is proof of trigonometric identity. So that students only write down the form of identity and then immediately prove it.

\subsection{Creating a completion plan}

Students formulate plans or strategies to solve problems. In the first problem, students use the program to solve the problem by converting time to seconds, then solving the issue by comparing the angle's size. As shown in Figure 4. For the second problem, students first illustrate the problem and then get a strategy using a trigonometric ratio that matches the situation. Student answers can be seen in Figure 5.

\section{- ubah waktu iputaran penuh ke derik}

Fig. 4. Students write down problem-solving steps 


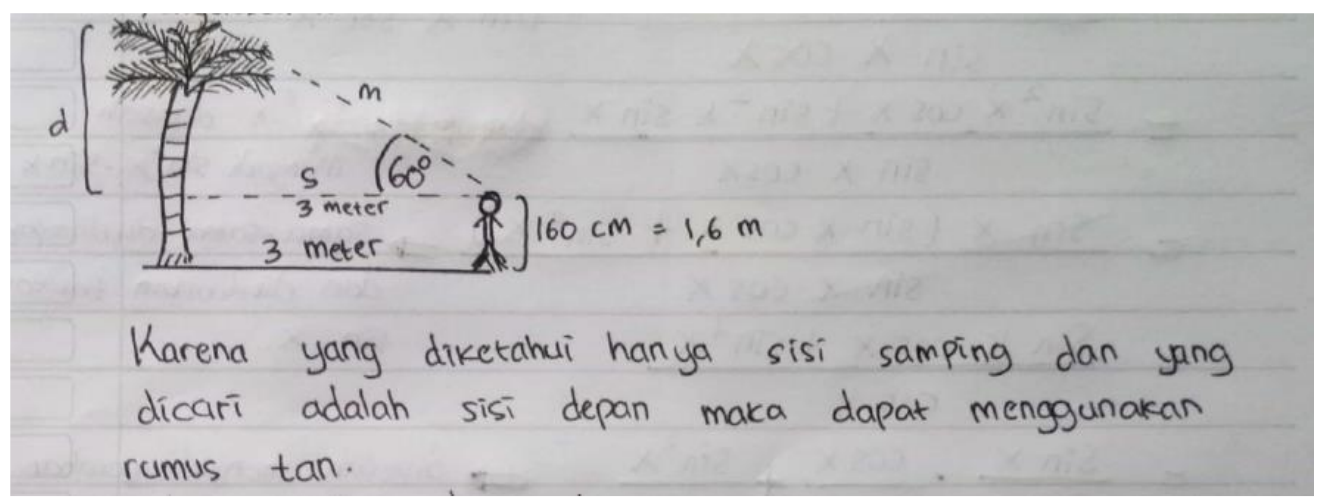

Fig. 5. Figure illustration of the problem

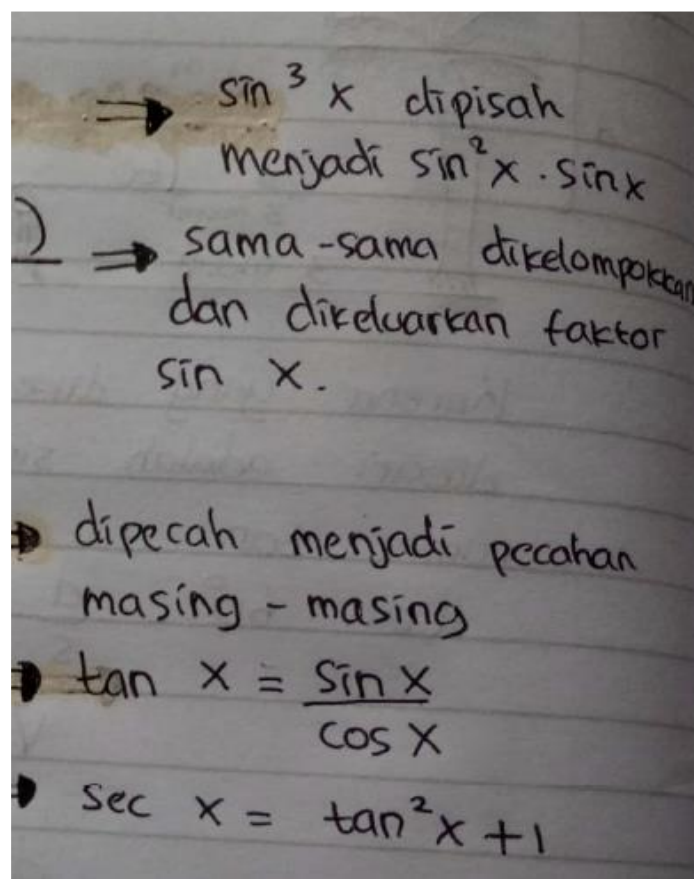

Fig. 6. Steps to prove trigonometric identity

In question number 3 , students compile a problem-solving plan by writing down the steps to get to the trigonometric form they want to prove, as figure 6 shows.

\subsection{Develop a problem-solving plan}

Students carry out the problem-solving plan that has been designed. In implementing the program, it is known whether the program is correct to lead to a problem? If it is correct, then the final answer is also correct. Figure 7 shows the implementation of the problem-solving plan for the first problem. Then, figure 8 shows the problem-solving method for the second problem. Figure 9 shows the performance of the problem-solving strategy for the third problem. However, in implementing these steps, there were misconceptions made by students. 


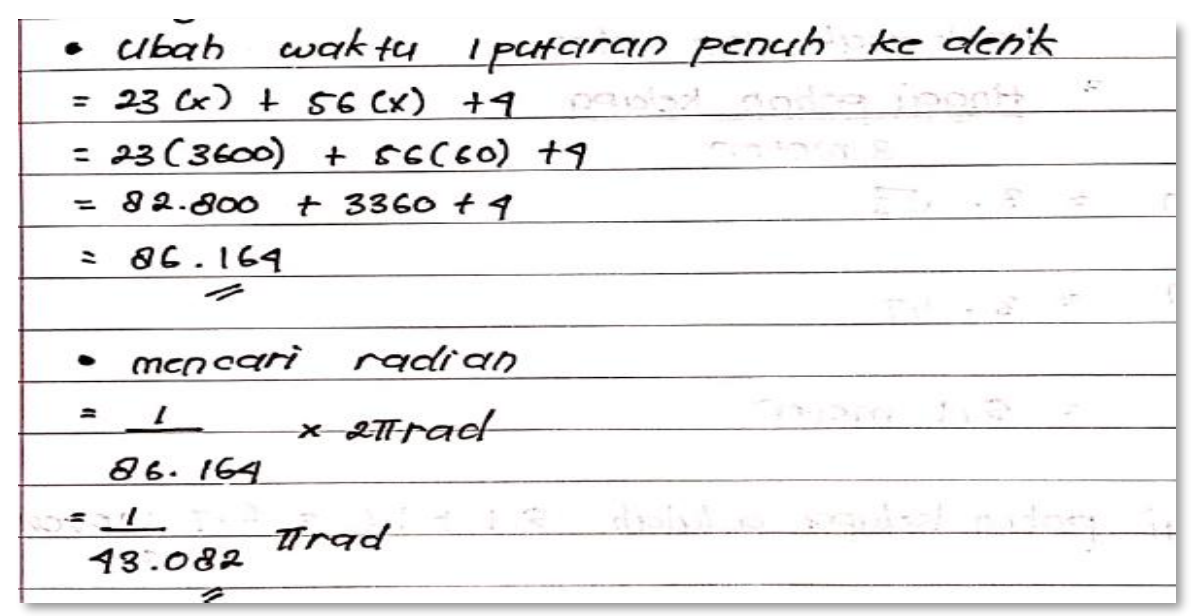

Fig.7. The implementation of the problem-solving plan for the first problem.

$\begin{aligned} & \begin{aligned} & \tan 60^{\circ}=\frac{d}{s}=\frac{d}{3} \\ & \sqrt{3}=\frac{d}{3} \\ & d=3 \times \sqrt{3}=5,1 \mathrm{~m} \\ & \text { Karena sudah diketahui sisi depan maka tingsi } \\ & \text { pohon kelapa bisa dicari dengan penambahan sisi } \\ & \text { depan dan tinggi anak. }\end{aligned} \\ & \text { Tinggi pohon kelapa }=5 i 5 i \text { depan tinggi anak } \\ &=5,1 \mathrm{~m}+1,6 \mathrm{~m} \\ &=6,7 \mathrm{~m}\end{aligned}$

Fig.8. The problem-solving plan for the second problem

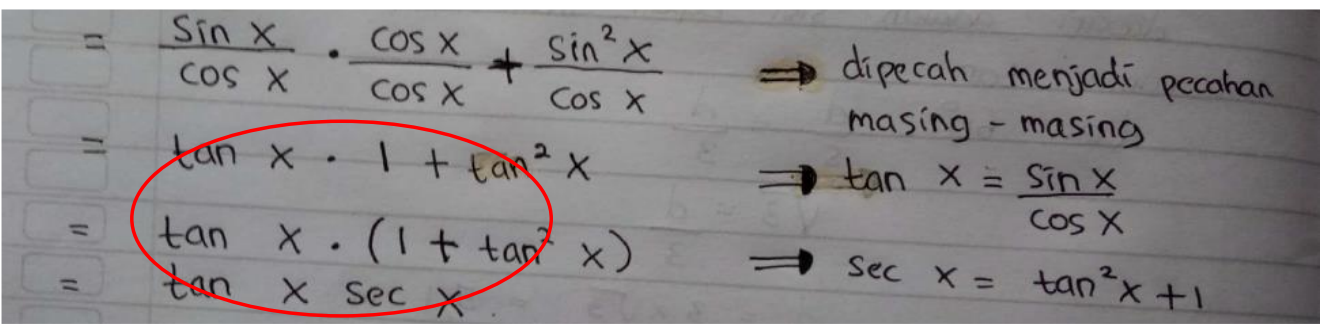

Fig.9. The implementation of the problem-solving plan for the third problem 


\subsection{Re-check the problem-solving results}

Students re-check the final answers that have been found. Based on the interview results, information was obtained that there were students who checked the results, and some were not because the processing time had run out. In general, from the three questions that have been answered by students. Based on the results of the study, it can be concluded that the subject understands the problem by identifying and writing down essential information by the questions being worked on. Besides, the issue compiles a problem-solving plan by writing down any steps that you want to take or making illustrations to solve the problem and determine the solution to the problem using the steps according to the plan. After that, check the results of the answers that have been done. The results of this study are by the results of research on the problemsolving abilities of prospective teacher students in linear program subjects [10], namely the issue can understand the problem by identifying the information that appears on the situation and determined using the simple method as a way of solving it by changing the story problem into a mathematical model. After that, finish with the simple process until you get the optimum solution and check the answer results that have been done again. However, in the third question related to trigonometric proof, students experienced a misconception. Following the research, one of the students' difficulties in answering trigonometric problem-solving problems is misconceptions [6]. The interview results also showed that students were still confused about what to do to prove their trigonometric identity correctly.

\section{Conclusion}

The result of this research is that the subject can understand the problem by identifying the information that appears on the issue and determining the method or formula used in solving the problem. After that, solve the trigonometric problems given and check the results of the answers that have been done. The trigonometric material provided in the problem-solving ability test is the size of the angle, trigonometry ratio, and trigonometric identity. Students still have difficulty completing proving trigonometric identities because students are still confused and also experienced misconceptions in trigonometric and algebraic properties to confirm this trigonometric identity. Suggestions for further research are that this research is continued with an experimental study on the trigonometric module's effectiveness to improve problem-solving abilities.

Acknowledgment. This research and development can be carried out well thanks to the resources of the Directorate General of Research and Development (Ditjen Risbang) Dikti. Not to forget our gratitude to the Institute for Research and Community Service and the mathematics education study program, University of Muhammadiyah Banjarmasin.

\section{References}

[1] H. Hendriana, E. E. Rohaeti, and U. Sumarmo, Hard Skills dan Soft Skills. 2017.

[2] A. In'am, Menguak penyelesaian masalah matematika (Analisis pendekatan metakognitif dan model polya). 2015. 
[3] A. A. Nugroho, D. Juniati, and T. Y. E. Siswono, "Self-regulated learning of prospective mathematics teacher in solving linear program problem : a case of visual learning style," Int. Conf. Math. Sci. Educ., vol. 3, pp. 820-824, 2018.

[4] V. May and S. Courtney, "Developing meaning in trigonometry," Illinois Math. Teach., vol. 63, no. 1, pp. 25-33, 2016.

[5] R. Nurmeidina and D. Rafidiyah, "Analysis of Students' Difficulties in Solving Trigonometry Problems," in Profunedu, 2019, DOI: 10.4108/eai.7-8-2019.2288422.

[6] H. Ahmad, F. Febryanti, M. Muthmainnah, A. Al Yakin, and S. Sarbi, "The Analysis of Student Error in Solve the Problem of Spherical Trigonometry Application," J. Phys. Conf. Ser., vol. 1114, no. 1, pp. 0-9, 2018, DOI: 10.1088/1742-6596/1114/1/012114.

[7] R. Nurmeidina, A. Lazwardi, and I. Ariyanti, "Pengembangan Modul Teori Peluang untuk Meningkatkan Hasil Belajar dan Disposisi Matematis," vol. 9, no. 2, pp. 440-450, 2020.

[8] S. Devesh and D. A. L. Nasseri, "Effectiveness of Mathematics Module in Foundation Programme in Majan College," Int. J. Emerg. Eng. Res. Technol., vol. 2, no. 1, pp. 1-7, 2014.

[9] A. D. Ismail, A. F. Jamil, and O. R. U. Putri, "Pengembangan Modul Trigonometri Bercirikan Open Ended Problem," AdMathEdu, vol. 7, no. 1, pp. 1-8, 2017.

[10] A. A. Nugroho and I. Dwijayanti, "Analisis Kemampuan Pemecahan Masalah Mahasiswa Calon Guru Matematika pada Mata Kuliah Program Linier," Aksioma J. Mat. dan Pendidik. Mat., vol. 10, no. 2, 2019. 